\title{
First record of Bythocaris cosmetops (Crustacea: Decapoda: Hippolytidae) in European waters
}

\author{
C. d'Udekem d'Acoz ${ }^{\ddagger}$ and J.C. Sorbe ${ }^{\dagger}$ \\ *Tromsø Museum (Department of Zoology), University of Tromsø, N-9037 Tromsø, Norway. \\ †Laboratoire d'Océanographie Biologique, UMR 5805 (CNRS/UBl), 2 rue Jolyet, 33120 Arcachon, France. \\ ${ }^{\ddagger}$ Corresponding author, e-mail: cdudekem@tmu.uit.no
}

\begin{abstract}
A single ovigerous female of Bythocaris cosmetops is recorded from the Bay of Biscay. This specimen is described and illustrated. This rare shrimp was previously known by a single specimen collected off tropical West Africa.
\end{abstract}

During the INTRIGAS and TROPHAL cruises, investigations on the shelf benthic communities from southern Brittany were performed at five sampling Sites A-E with various modern quantitative samplers. During the sorting of the material collected with a Roscoff suprabenthic sledge, one specimen of the hippolytid shrimp Bythocaris cosmetops Holthuis, 1951 was encountered. This species was previously known by a single specimen collected off West Africa. The present shrimp record is discussed here. The specimen has been deposited in the Muséum National d'Histoire Naturelle, Paris (MNHN).

\section{SYSTEMATICS}

Order DECAPODA Latreille, 1803

Infraorder CARIDEA Dana, 1852

Family HIPPOLYTIDAE Dana, 1852

Genus Bythocaris G.O. Sars, 1870

Bythocaris cosmetops Holthuis, 1951

(Figure 1)

\section{Material examined}

One ovigerous female, total length $13 \mathrm{~mm}$ (TROPHAL cruise, 14 September 2002, 2315-2336 h), RV 'Thalassa', Roscoff suprabenthic sledge, sample reference DD1TS08N-N1, 'Grande Vasière', $46^{\circ} 50^{\prime} \mathrm{N} \quad 03^{\circ} 45^{\prime} \mathrm{W}, 120-$ $121 \mathrm{~m}$ depth, 10-40 cm above bottom, muddy medium sands (silt and clay: 8.8-10.12\%; sand: 90.7-89.7\%; gravel: $0.5-0.2 \%$ ), temperature: $10.96 \pm 0.05^{\circ} \mathrm{C}$ (mean\pm standard error)) [MNHN Na 15151].

\section{Diagnosis}

Rostrum more or less horizontal, much shorter than eyestalks, reaching only basis of stylocerites. Supraorbital teeth in very lateral position, forming a wing-like expansion with rostrum. Middle of carapace with an anteriorly truncated tooth. Hepatic spine absent. Eyestalk with elliptic expansion on mesial side; cornea dark. Scaphocerite rounded anteriorly. Ischium of first pereiopod with seven distoventral spines on outer side. Basis of second pereiopod with one distoventral strong seta; carpus with eight articles. Third pereiopod robust, slightly overreaching scaphocerite; merus with six irregular-sized ventrolateral spines on its distal half; propodus with eight groups of 1-2 ventral spines spread on all its length; length of propodal spines gradually increasing in size towards tip (spines of five distal groups rather long and fairly robust); dactylus with terminal unguis +eight ventral spines. Merus of fourth pereiopod with three ventrolateral spines; merus with nine groups of 1-2 spines. Fifth pereiopod lost. Pleuron 1 narrowly elliptic (slightly pointed on right side). Pleura $2-5$ pointed. Eggs large; maximum diameter $=0.8-0.9 \mathrm{~mm}$. Some very small chromatophores distinct on pleonite 6 and tail fan one year after fixation.

Remarks

Our European specimen seems very similar to the African holotype as described by Holthuis (1951). Only the following differences were noted. In the European specimen the rostrum is slightly longer than in the holotype, the ischium of the first pereiopod has seven distoventral spines instead of one, and its second pleuron has an obtuse tooth instead of being rounded. These differences can probably be attributed to individual variation. The ambulatory pereiopods were lacking in the holotype and it is therefore the first time that information is available for them.

The genus Bythocaris has been revised by Fransen (1993) and Sokolov (2000). Most species live in sub-Arctic to high Arctic waters and are usually bathyal. Bythocaris cosmetops is however a remarkable exception. It was first discovered in tropical West Africa, off Sierra Leone, $07^{\circ} 29^{\prime} \mathrm{N} 13^{\circ} 38^{\prime} \mathrm{W}$, on muddy sand at only 74-78 m (Holthuis, 1951). Its type material consisted of a single incomplete ovigerous female. This species has never been found again after its original description. So, it was a considerable surprise to find it in the Bay of Biscay, an area well studied for its decapod fauna.

The only previous record of the genus Bythocaris in the Bay of Biscay consists of four specimens of an undescribed species collected on the Mériadzek terrace at 1920-2360 m (de Saint Laurent, 1985). Our Bythocaris cosmetops specimen (1 ovigerous female) was sampled in a night-time suprabenthic haul on muddy medium sands from Site D of the 'Grande Vasière' fishing grounds. Bythocaris cosmetops has previously not been recorded in that area, despite intensive 


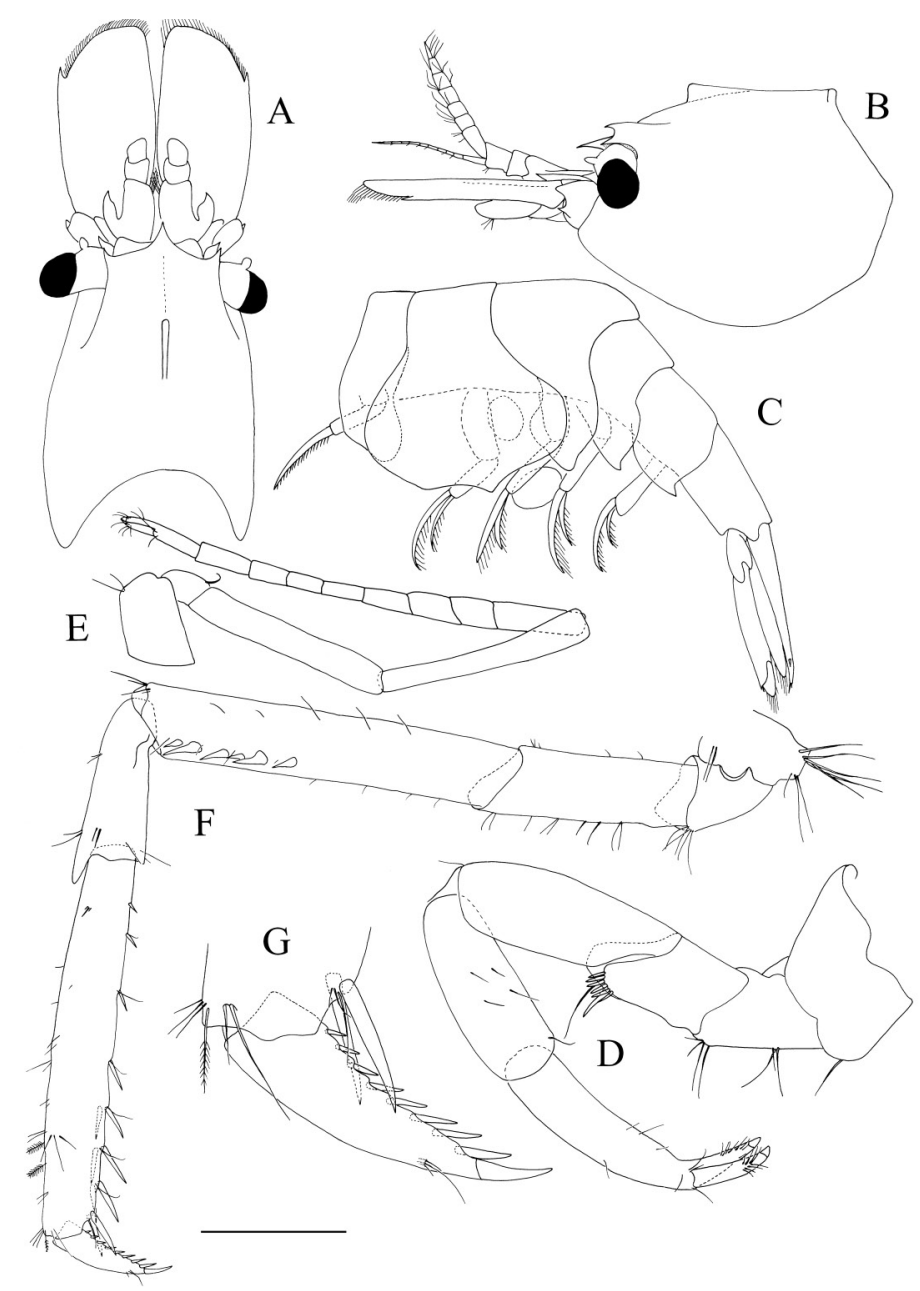

Figure 1. Bythocaris cosmetops Holthuis, 1951, Bay of Biscay: (A) anterior part of body in dorsal view; (B) anterior part of body in lateral view; $(\mathrm{C})$ posterior part of body in lateral view; (D) left first pereiopod; (E) left second pereiopod; (F) left third pereiopod; (G) dactylus of left third pereiopod. Scale bar: A,B, $1.77 \mathrm{~mm}$; C, $2.48 \mathrm{~mm}$; D, $0.42 \mathrm{~mm}$; E,F, $0.60 \mathrm{~mm}$; G, $0.21 \mathrm{~mm}$.

dredging. These fishing grounds were intensively sampled at five selected Sites A-E (34 suprabenthic hauls from 94 to $143 \mathrm{~m}$ water depth) during INTRIGAS and TROPHAL cruises. Bythocaris cosmetops was absent in all 24 daytime hauls and only detected in a night-time haul from Site D (10-40 cm near-bottom water layer). Therefore, this small species must be considered as very rare in the area and perhaps only exceptionally captured when swimming freely in the near-bottom water layer during night-time. Very little is known about the biology of other Bythocaris species. Some species like B. simplicirostris G.O. Sars, 1870 are known to be suprabenthic, whilst others like B. leucopis G.O. Sars, 1879 and B. payeri (Heller, 1875) are benthopelagic (Brattegard \& Rømer, 1998). The present B. cosmetops specimen was collected in the so-called 'thermic bell', a cold bottom water mass $\left(<11.5^{\circ} \mathrm{C}\right)$ centred along the mid-continental shelf (including the 'Grande Vasière' area) that maintains lower temperature conditions all year round. This is consistent with the boreal/Arctic and deep-sea distribution of most Bythocaris species, which have obvious affinities for cold waters, but conflicts with the tropical and circalittoral origin of the holotype of $B$. cosmetops.

The authors are most grateful to the crew of the RV 'Thalassa' as well as to all participants of the TROPHAL cruise for their assistance. Thanks to GIRMAT/CNRS for the loan of the suprabenthic sledge, to N. Peralta (Leonardo da Vinci, Universidade de Aveiro) for sorting the samples, to F. Le Loc'h (UBO, Brest) for the environmental data registered during INTRIGAS and TROPHAL cruises. This study was partially supported by the French 'Programme National Environnement Côtier' within the framework of the project 'Dynamique et forçage anthropique des peuplements benthiques du golfe de Gascogne' directed by J. Boucher (IFREMER, Brest) and C. Hily (CNRS/UBO, Brest).

\section{REFERENCES}

Brattegard, T. \& Rømer, E.I., 1998. Decapoda Natantia (Crustacea) in the Faroe Area. Fródskaparrit, 46, 91-126.

Fransen, C.H.J.M., 1993. Notes on the genus Bythocaris G.O. Sars, with the description of a new species. Zoologische Mededelingen, Leiden, 67, 567-599.

Holthuis, L.B., 1951. The Caridean Crustacea of Tropical West Africa. Atlantide Report, 2, 7-187.

Saint Laurent, M. de, 1985. Remarques sur la distribution des crustacés décapodes. In Peuplements profonds du golfe de Gascogne (ed. L. Laubier and C. Monniot), pp. 469-478. IFREMER.

Sokolov, V., 2000. Deep-sea shrimps of the genus Bythocaris G.O. Sars in the collections of Russian museums, with the description of a new species (Crustacea: Decapoda: Hippolytidae). Zoologische Mededelingen Leiden, 74, 403-468.

Submitted 13 April 2004. Accepted 25 June 2004. 